\title{
National Legislations on Inclusive Education and Special Educational Needs of People with Autism in the Perspective of Article 24 of the CRPD
}

\author{
Rachele Cera
}

\section{Introduction}

Education is vital not only in itself, but also for participating in all areas of social activity. In poet, the right to education works as a multiplier by enabling people to exercise other human rights. It enhances both economic, social and cultural rights, such as the right to work and the right to food, and civil and political rights, like the right to vote and the freedom of expression. Being its realization a precondition for socio-economic inclusion and full participation in society, the right to education has, therefore, been recognized as an example of the indivisibility and interdependence of all human rights on account of its key role in the full and effective realization of other rights. ${ }^{1}$

Historically people with disabilities have often suffered, and in most parts of the world are still suffering, from a pervasive and disproportionate denial of the right to education. In many countries, children with disabilities are sent away to institutions where they receive no education and are isolated from society for their entire lives. In other countries, children with disabilities are forced to attend separate schools instead of general schools in the community. The vast barriers children with disabilities face in accessing education in most societies has led to a low employment rate for persons with disabilities and a disproportionately high rate of poverty.

In such context, international law plays as a facilitator for the realization of the right to education of people with disabilities throughout the world. As the most

\footnotetext{
${ }^{1}$ UN Committee on Economic, Social and Cultural Rights (CESCR) General Comment No. 11: Plans of Action for Primary Education (E/1992/23), 10.5.1999, and General Comment No. 13: The Right to Education (E/C.12/1999/10), 8.12.1999.

R. Cera $(\square)$ Institute for International Legal Studies, National Research Council (CNR), Rome, Italy e-mail: rachele.cera@cnr.it
} 
recent, integral and legally binding international instrument to protect the rights of persons with disabilities, the Convention on the Rights of Persons with Disabilities (CRPD) put steps forwards for the protection of their right to education.

The normative impetus behind the CRPD is inclusive equality of disabled people in all socio-economic sectors. In this vein, Article 24 of the CRPD specifically responds to the legacy of exclusion and marginalization of disabled learners in the education sector by guaranteeing the right to equality and non-discrimination in State provision of education. More significantly, Article 24 breaks new ground by recognizing 'inclusive education' as a human right. The recognition of inclusive education as a human right is largely a culmination of global advocacy for an education system that is inclusive as to accommodate diverse learning needs and capacities. $^{2}$

\section{Definitions of Inclusive Education and Special Educational Needs: The ASD Perspective}

From a legal point of view, there is no consensus on the definition of the concept of 'inclusive education'. Neither the CRPD provides for such a definition.

What is clear, however, is what it is not. Inclusive education is obviously not equal to education in special schools, especially when no choice is given to people with disabilities to refuse their enrolment in such schools. ${ }^{3}$ But neither is inclusive education equal to integration, which would simply provide access to regular schools for children with disabilities without allowing them to be educated there in a way that takes account of their special needs. This interpretation is confirmed in the Concluding observations of the Committee on the Rights of Persons with Disabilities (CRPD Committee) to Austria's initial report, noting that 'there is some confusion between "inclusive" education and "integrated" education' in that State.

Inclusive education recognizes that all children are different and acknowledges that children with disabilities should be able to participate in the general education system. By taking into account the diversity among learners, it seeks to combat discriminatory attitudes, create welcoming communities, achieve education for all as well as improve the quality and effectiveness of education of mainstream learners. ${ }^{4}$

\footnotetext{
${ }^{2}$ See Arnardóttir (2011), pp. 219-221.

${ }^{3}$ The terms 'mainstream schools', 'general education', 'regular schools' and 'ordinary schools' are commonly used to refer to schools systems that receive students with or without impairments as opposed to 'special schools' that only receive students with impairments.

${ }^{4}$ OHCHR-Office of the United Nations High Commissioner for Human Rights The right to education of persons with disabilities. Report of the Special Rapporteur on the Right to Education (UN Doc A/HRC/4/29), 19.2.2007, para. 9.
} 
According to the Office of the UN High Commissioner for Human Rights (OHCHR), inclusion is 'a process that recognizes: (a) the obligation to eliminate barriers that restrict or ban participation, and (b) the need to change culture, policy and practice of the mainstream schools to accommodate the needs of all students, including those with impairments'. 5 It requires 'accommodating both different styles and rates of learning and ensuring quality education to all through appropriate curricula, organizational arrangements, teaching strategies, resource use and partnerships with their communities'.

The idea underlying inclusive education is that some children, because of their impairments or other circumstances, have special needs in education which prevent them to benefit from the school education made generally available for children of the same age without additional support or adaptations in the content of studies.

Defining Special Educational Needs (SEN) has an administrative function whereby a group of students is identified for different or additional educational provision. No universally accepted system of SEN classification exists. Definitions of SEN vary widely across countries as they are specific to each domestic legislation. Some countries define SEN using a general definition covering a wide range of needs including a wide range of physical, mental, cognition or educational impairments. Others categorize SEN according to a disability classification system with a different number and types of disabilities. ${ }^{6}$

Education is the primary form of treatment in autism, as it fosters the acquisition of skills or knowledge-including not only academic learning, but also socialization, adaptive skills, language and communication, and reduction of behavior problems-and it assists a child to develop independence and personal responsibility. ${ }^{7}$

Because of the very nature of the disorder, students with Autism Spectrum Disorder (ASD) are commonly recognized as having special educational needs. ${ }^{8}$ In some countries, autism appears in a specific normative category within SEN classification (such as in Czech Republic, ${ }^{9}$ Hungary, ${ }^{10} \mathrm{USA}^{11}$ ); in others, where classification does not pursue to disabilities but to type of difficulties, autism falls within other categories and professional judgment plays a larger part in identification.

\footnotetext{
${ }^{5}$ OHCHR-Office of the United Nations High Commissioner for Human Rights Thematic study on the right of persons with disabilities to education (UN Doc A/HRC/25/29), 18.12.2013, para. 7.

${ }^{6}$ See Reindal (2008). Disability classification systems have been criticised for categorising impairments and special needs into disabilities, through classification systems grounded in a medical understanding of disability.

${ }^{7}$ See Lord and McGee (2001).

${ }^{8}$ See King (2006).

${ }^{9}$ Act No. 561 on Pre-school, Basic, Secondary, Tertiary Professional and Other Education (the Education Act) of 2004, Section 16.

${ }^{10}$ Act CXC on National Public Education of 2011, Section 4.

${ }^{11}$ Individuals with Disabilities Education Act (IDEA) of 2004, Sec. 300.8.
} 
It is argued if, given their specific learning needs, students with ASD would require an alternative educational approach than that applied for students without ASD and specialized instructional techniques and learning environments would be recommended for them. ${ }^{12}$

The challenge of inclusive education is to fulfill the right to education by providing access for persons with disabilities to a high-quality and meaningful place in education system. This objective can be reached by adapting education to the needs of persons with disabilities. Excluding people with autism from the inclusive education process would increase stereotypes and negative attitudes towards them. In fact, the UN General Assembly Resolution 67/82 of 19 March 2013 stressed on the importance of enhancing inclusive educational programmes suited to infants, children and adults with autism as part of an integrated approach for addressing ASD. Furthermore, in its message on the World Autism Awareness Day of 2 April 2014, the UN General Secretary emphasized the key value of education for people with autism since 'schools connect children to their communities. By including children with different learning abilities in mainstream and specialized schools, we can change attitudes and promote respect'.

\section{The Right to Inclusive Education: The International Policy Framework}

While the CRPD is the first legally binding instrument to protect the right to inclusive education, the idea was already expressed in previously adopted international instruments.

The shift towards an inclusive approach to education was reflected at the 1990 World Conference on Education for All, by which the problem of the exclusion of students with disabilities from school systems was acknowledged. Following the Conference, the World Declaration on Education For All: Meeting Basic Learning Needs (Jomtien Declaration) declared that 'steps need to be taken to provide equal access to education to every category of disabled persons as an integral part of the education system'. 13

The adoption in 1993 of the Standard Rules on the Equalization of Opportunities for Persons with Disabilities provided for integration in mainstream schools affirming that 'education for persons with disabilities should form an integral part of national educational planning, curriculum development and school organisation" ${ }^{, 14}$ and that 'education in mainstream schools presupposes the provision of

\footnotetext{
${ }^{12}$ See Renty and Roeyers (2005).

${ }^{13}$ UNESCO (1990) World Declaration on Education For All: Meeting Basic Learning Needs, Article 3 (5).

${ }^{14}$ UNGA Resolution 48/96 Standard Rules on the Equalization of Opportunities for Persons with Disabilities (A/RES/48/96), 20.12.1993, Rule 6 (1).
} 
interpreter and other appropriate support services' and 'adequate accessibility and support services, designed to meet the needs of persons with different disabilities' ${ }^{15}$ However, it also recognised that 'in situations where the general school system does not yet adequately meet the needs of all persons with disabilities, special education may be considered' but 'should be aimed at preparing students for education in the general school system'. ${ }^{16}$

It was not until the UNESCO World Conference on Special Needs Education: Access and Equality in 1994 that, for the first time, specific attention was paid to the right to inclusive education in particular. Signed by 92 Governments, the resulting Salamanca Statement required mainstream schools to provide quality education to all students, including students with disabilities, without discriminating on the basis of the higher requirements of support that they may need. The Salamanca Statement proclaimed that every child has unique characteristics, interests, abilities, and learning needs and provided that 'those with special educational needs must have access to regular schools which should accommodate them within a child-centred pedagogy capable of meeting these needs'. It also asserted that 'regular schools with this inclusive orientation are the most effective means of combating discriminatory attitudes, creating welcoming communities, building an inclusive society and achieving education for all'. ${ }^{17}$

Subsequently, the Dakar Framework for Action on Education for All adopted in 2000 a World Declaration on Education for All affirming the notion of education as a fundamental right and establishing the new millennium goal to provide every girl and boy with primary school education by 2015. To this end, the Declaration stressed that education systems must be inclusive and respond flexibly to the circumstances and needs of all learners. Children with disabilities were not explicitly mentioned in this framework but implicitly included in references to most vulnerable and disadvantaged children. However, it has been noted that the lack of reference to particular minority groups by name, without consequently articulating strategies most appropriate for their inclusion, may have led to a lesser response by governments than has been the case when addressing the needs of more clearly stated groups. ${ }^{18}$

The above-mentioned international legal instruments are not legally binding on Member States. ${ }^{19}$ Neither they provide for monitoring of their implementation. Conventions, instead, do constitute binding international law on the States that ratify them.

\footnotetext{
${ }^{15}$ Standard Rules, Rule 6 (2).

${ }^{16}$ Standard Rules, Rule 6 (3).

${ }^{17}$ World Conference on Special Needs Education: Access and Equality, Salamanca Statement and Framework for Action on Special Needs Education, Salamanca, 7-10.6.1994, paras. 2 and 3, http://unesdoc.unesco.org/images/0009/000984/098427eo.pdf, accessed 17 Sep 2014.

${ }^{18}$ UNESCO (2009).

${ }^{19}$ According to some commentators, the Standard Rules have achieved "customary law" law status through legislation conforming to these rules in a significant number of States.
} 
Until the CRPD, the Convention on the Rights of the Child (CRC) was the only treaty containing provisions on inclusive education for children and youth with disabilities. Recognizing the special needs of disabled children, Article 23 of the CRC requires State to provide assistance designed to ensure that the disabled child has effective access to and receives education. However, Article 23 has been strongly challenged by Disabled People Organizations (DPOs) because its wording makes rights contingent on 'available resources', allowing States a large degree of discretion concerning allocation of resources to special needs education.

In 2006, building on these precedents, the CRPD gave legally binding status to the concept of 'inclusive education', which is recognized as the only mean to ensure the right to education to all students, including persons with disabilities, without discrimination and on equal terms with others. In other words, in the Convention it is underscored that the right to education is in fact the right to inclusive education.

\section{The Action of the European Union}

Disability as a social aspect lies within the so-called supporting competency of the European Union (EU) and this is also true when talking about education-especially inclusive education - because there is no explicit EU competence on children with disabilities. In fact, Article 165 of the Treaty on the Functioning of the European Union (TFEU) confers only a supporting competence upon the EU in the field of education. Hence, the European Union can only encourage cooperation between Member States by supporting and supplementing their action, where necessary, and must respect their responsibility for the content of teaching and the organization of education systems and their cultural and linguistic diversity.

Within such a limited competence, the EU has adopted some acts addressing and promoting inclusive education.

By its Resolution on equal opportunities for pupils and students with disabilities in education and training of 5 May 2003, the EU Council invites Member States and the Commission, within their respective competencies, 'to encourage and support the full integration of children and young people with special needs in society through their appropriate education and training, and their insertion in a school system which is adapted to their needs, ${ }^{20}$ It specifically recommends measures as regards assistance, information, training, and exchanges of good practices.

The Communication on Improving Competences for the 21st Century: An Agenda for European Cooperation on Schools of the Commission, of 3 July

\footnotetext{
${ }^{20}$ Council Resolution on equal opportunities for pupils and students with disabilities in education and training, 5.5.2003.
} 
$2008,{ }^{21}$ recognizes that achieving inclusion while supporting those with specific needs involves re-thinking policies for organizing learning support, improving collaboration between schools and other services, and implementing personalized learning. The Communication proposes to focus future cooperation on 'providing more timely support and personalized learning approaches within mainstream schooling for students with special needs, among other things'.

'Education and training' is one of the eight priority areas under the Disability Strategy 2010-2020. ${ }^{22}$ The specific goal is to promote inclusive education and lifelong learning for pupils and students with disabilities. The Strategy lists a series of actions to ensure that people with disabilities receive the support required within the general education system to facilitate their education, and that effective individualized support measures are provided in environments that maximize academic and social development, consistent with the goal of full inclusion.

The goal of inclusive education and training is supported within the framework of the Youth and Move Initiative which promotes actions for the exchange of good practices on inclusive education and dissemination of guidance materials on the principle of reasonable accommodation in education. The initiative, which includes a commitment to reducing school drop-out rates and increasing participation in tertiary education, is expected to have an impact on inclusive education and job placement schemes for young people with disabilities.

Furthermore, the Strategy provides for the EU supports to national efforts through the Education and Training 2020 (ET 2020) framework, which establishes common strategic objectives for Member States. One of its four strategic objectives is promoting equity, social cohesion and active citizenship. In the context of ET2020, the 2013 report 'Supporting Teachers' Competence Development for Better Learning Outcomes' acknowledged the need for teachers to possess the knowledge, skills and attitudes to deal with diversity and inclusion.

A stronger EU action can be found in the field of non-discrimination based on disability.

The Treaty on the Functioning of the European Union established the legal basis for the EU action to combat discrimination (Article 19), providing that the Council may take appropriate action to combat discrimination based on disability.

Currently, the EU anti-discrimination law covers to the educational field at least to a limited extent. The Employment Equality Directive ${ }^{23}$ includes within its

\footnotetext{
${ }^{21}$ Communication from the Commission to the European Parliament, the Council, the European Economic and Social Committee and the Committee of the Regions Improving competences for the 21st Century: an Agenda for European Cooperation on Schools (COM/2008/0425 final), 3.7.2008.

${ }^{22}$ Communication for the Commission to the European Parliament, the Council, the European Economic and Social Committee and the Committee of the Regions European Disability Strategy 2010-2020: A Renewed Commitment to a Barrier-Free Europe (COM(2010) 636 final), 15.11.2010.

${ }^{23}$ Council Directive establishing a general framework for equal treatment in employment and occupation (2000/78/EC), 27.11.2000.
} 
material scope the field of vocational training, which has been defined by the EU Court of Justice as 'any form of education which prepares for a qualification for a particular profession, trade or employment or which provides the necessary training and skills for such a profession, trade or employment [...] even if the training programme includes an element of general education'.

In 2008, the Commission adopted a proposal for a Multi-Ground BeyondEmployment Directive aimed at extending the protection against discrimination on the grounds of religion or belief, disability, age or sexual orientation to areas outside employment, including education. ${ }^{24}$

A large majority of delegations welcomed the proposal in principle, many endorsing the fact that it complements the existing EU legal framework by addressing all four grounds of discrimination through a horizontal approach and underlining the significance of the proposal in the context of the implementation of the CRPD.

The genuine novelty in the definition of discrimination in Article 2 (2) (5) is the proposal to create a fifth limb to the concept of discrimination which would be the 'denial of reasonable accommodation'. This is an advancement with respect to the Employment Directive which does not clearly include such a failure within its definition of 'discrimination'. It can be only presumed by the preface of the duty reading 'in order to guarantee compliance with the principle of equal treatment in relation to persons with disabilities'. By stating that the denial of reasonable accommodation is a specific form of unlawful discrimination, the proposed Directive endorses the approach of the CRPD.

Another positive aspect is the establishment in Article 4 (1) (a) of an anticipatory duty to provide 'effective non-discriminatory access to social protection, social advantages, health care, education and access to and supply of goods and services which are available to the public, including housing and transport'. The Directive does not spell out on whom this duty falls, but it implies that Member States and service-providers have a positive obligation to take measures to ensure equal access for disabled persons.

However, in the field of disability, some delegations would have preferred more ambitious provisions within the proposed Directive.

One of the most debated provisions concerns the restrictions to the application of the Directive under Article 3. This article concerns the material scope of the Directive, therefore strictly speaking, these provisions are not exceptions to the prohibition of discrimination, but simply limitations on the scope of application of the Directive. In particular, such provision provides that the Directive is 'without prejudice' to the content of teaching, organization of the educational system, including special needs education.

\footnotetext{
${ }^{24}$ Proposal for a Council Directive on implementing the principle of equal treatment between persons irrespective of religion or belief, disability, age or sexual orientation (COM/2008/0426 final-CNS 2008/0140), 2.7.2008.
} 
Such provision raised many criticisms. First, 'special needs education' are not defined and therefore it appears unclear whether the proposal only intends to reserve this concept for specialized schools, or whether it also includes mainstream schools that provide reasonable accommodations (such as an adapted curriculum, or provision of tuition in alternative communication means) for children with special educational needs.

Secondly, it is unclear if the restriction excludes all aspects of 'special needs education' from the scope of the Directive, or only those aspects which relate to 'the content of teaching, activities and organization' of special needs education. If all aspects of 'special needs education' fall outside the scope of the Directive then, for example, a child who experiences discrimination on one of the prohibited grounds at a mainstream school would be protected, whilst a child who is victim of a similar discriminatory treatment in a 'special needs' setting would not be.

The EU Parliament tackled such concerns in its resolution of 2 April 2009 on the proposal Directive, by introducing an amendment to Article $3 .^{25}$ While it confirms that the Directive shall not apply to the content of teaching, activities and organization of national educational systems, the amendment obliges Member States to ensure the right of persons with disabilities to education without discrimination and on the basis of equal opportunities. In addition, it requires Member States to ensure that, in determining which type of education or training is appropriate, the views of the person with disabilities are respected.

While emphasizing the importance of such new Directive for the fight against discrimination, certain delegations have general reservations, questioning the need for the Commission's proposal, which they see as infringing on national competence for certain issues and as conflicting with the principles of subsidiarity and proportionality.

The European Union formally ratified the UN Convention on the Rights of Persons with Disabilities on 23 December 2010. The commitments deriving from the Convention argue for the EU to take an active role on education, hopefully moving forward the process for adopting the proposal Directive.

\section{Article 24 of the CRPD}

The normative construction under the CRPD is a ringing rejection of conceiving disability as individual impairment and equality as formal equality. It sees disability through the lens of a human rights model of disability whose ultimate focus is not on identifying intrinsic impairment, but on the interaction between impairment and

\footnotetext{
${ }^{25}$ European Parliament legislative resolution on the proposal for a Council directive on implementing the principle of equal treatment between persons irrespective of religion or belief, disability, age or sexual orientation (COM(2008)0426-C6-0291/2008-2008/0140(CNS)), 2.4.2009.
} 
the environment and on overcoming systemic barriers in order to accommodate different disabilities.

Article 24 of the CRPD provides even in the most straightforward way for inclusion in the entire Convention and increases the chances of people with disabilities to enjoy equal treatment. As the other UN thematic human rights treaties, the CRPD does not establish a new right, but rather it clarifies the specific implications for persons with disabilities of enjoying the right to education without discrimination and sets out the obligations for Contracting Parties to ensure education systems are inclusive for persons with disabilities.

\subsection{The Right to Inclusive Education}

The drafters of the CRPD did not immediately agree on the right to inclusive education. There was a lot of discussion in this regard, where among others the question arose whether or not special education still had to be made available. The Ad Hoc Committee, charged with elaborating the Convention, initially left persons with disabilities the right to choose between inclusive and special education. Draft Article 17 (3) of the CRPD provided that "where the general education system does not adequately meet the needs of persons with disabilities special and alternative forms of learning should be made available'. Any such forms should:

a) reflect the same standards and objectives provided in the general education system;

b) be provided in such a manner to allow children with disabilities to participate in the general education system to the maximum extent possible;

c) allow a free and informed choice between general and special systems;

d) in no way limit the duty of States Parties to continue to strive to meet the needs of students with disabilities in the general education system. ${ }^{26}$

The intent of this draft Article was to provide the right to choose inclusive and accessible education. There is no intention to create an obligation on students with disabilities to attend general schools where their needs may not be adequately met.

This provision reflected the different opinions among the drafters regarding the right to education of persons with disabilities. While some delegations considered that choice was an important element of this Article, some others considered that the right to education was more important. Other members would have liked greater emphasis on the best interests of the child in this choice. In this regard, different

\footnotetext{
${ }^{26}$ Ad Hoc Committee on a Comprehensive and Integral International Convention on the Protection and Promotion of the Rights and Dignity of Persons with Disabilities Working Group Report of the Working Group to the Ad Hoc Committee. Annex I: Draft articles for a Comprehensive and Integral International Convention on the Protection and Promotion of the Rights and Dignity of Persons with Disabilities (A/AC.265/2004/WG.1), 27.1.2004. http://www.un.org/esa/socdev/ enable/rights/ahcwgreportax1.htm. Accessed 17 Sep 2014.
} 
approaches were also identified to setting out the relationship between the provision of specialist education services and the general education system. While some drafters considered that both mainstream and special schools should exist in parallel, others thought that inclusive education should be the norm and special education the exception.

In the meanwhile, the Committee on the Rights of the Child adopted General Comment No. 9 on the rights of children with disabilities, which likewise provided that inclusive education must be the objective of education for children with disabilities. However, it also recognized that 'the measure in which the inclusion occurs may vary' and that 'a continuum of services and programme options must be maintained in circumstances where fully inclusive education is not feasible to achieve in the immediate future'. ${ }^{27}$

The drafters of the CRPD laid down the principle that inclusive education has to be guaranteed for all persons with disabilities. Article 24 (1) of the CRPD establishes that 'States Parties shall ensure an inclusive education system at all levels and lifelong learning'.

Article 24 (2) (a) and (b), of the CRPD further stipulates that the States Parties shall ensure that 'children with disabilities are not excluded from free and compulsory primary education on the basis of disability' and that 'persons with disabilities can access an inclusive, quality and free primary education and secondary education on an equal basis with others in the communities in which they live'. Consequently, children with disabilities may not be denied education because of their impairments and must, together with their parents, be able to opt for regular schools in their neighborhood.

The right to education of persons with disabilities may be achieved over a certain period of time. In fact, Article 4 (2), of the CRPD provides that economic, social and cultural rights have to be progressively realized within the maximum available resources. The progressive realization of the right to education of persons with disabilities does not mean that inclusive education can just be postponed. Contracting Parties should make greater efforts to comply with the obligation to progressively realize the right to inclusive education within the maximum available resources. States Parties must take steps to this end, even though the objective does not have to be reached right away, and put in place their resources with a view to fully realize the right to education by providing reasonable accommodations and adopting support measures. As a best practice of fulfilling the purpose of Article 24, in conformity with Article 4 (2) of the Convention, in its Concluding observations on the initial report of Spain, the CRPD Committee commended the State Party for the high percentage $(78.35 \%)$ of enrolment of children with disabilities in

\footnotetext{
${ }^{27} \mathrm{UN}$ Committee on the Rights of the Child General Comment No. 9 (2006): The rights of children with disabilities (CRC/C/GC/9), 27.2.2007, para. 66 .
} 
the regular education system, and for 'the efforts made to maintain the funding for programmes for persons with disabilities in times of economic crisis. ${ }^{28}$

In this regard, it must be said that an inclusive education system is not more expensive than a segregated education system. According to UNICEF, 'countries are now increasingly realizing the inefficiency of multiple systems of administration, organizational structures and services, and that it is the option of special schools which is financially unrealistic'. ${ }^{29}$ Inclusive education could bring additional costs in the short term and only become profitable in the long term.

The question is what must be done about special schools.

Special education is specifically provided in Article 24 (3) (c) of the CRPD for persons with sensory or communication impairments in order to reflects the opinions expressed during the negotiations by their representative organizations fearing that inclusive education would neglect the identity of deaf and blind children and would in practice mean exclusion. The result is that persons with sensory or communication impairments should be allowed to be educated in special schools, although this option should not prevent them from asking to be able to participate in the general education system.

Beyond the exception for blind, deaf or deaf-blind children contained in Article 24 (3) (c), there is still ambiguity on special schools.

The proposal made by the Centre for Studies on Inclusive Education (CSIE) to prohibit providing special education for children with disabilities was rejected. ${ }^{30}$ Even though any reference to special education has been deleted, it is still debated to what extent special schools are allowed under the Convention. Article 24 (2) (e), in fact, seems to make room for special education, stating that 'effective individualized support measures are provided in environments that maximize academic and social development, consistent with the goal of full inclusion'.

It cannot be ruled out that for a limited number of children with serious and multiple disabilities reasonable accommodations are not possible or support measures not desired. Consequently, it could be that mainstream education is not achievable for these children. Article 24 does not prevent States from establishing special schools for these children. Nor, however, does it compel them to be equipped with special schools, as was confirmed during the negotiations. ${ }^{31}$ In other words, while such schools can be established for some children with disabilities, there is no requirement to have them. States, thus, have a certain leeway, although they should provide a strong CRPD-based justification if they keep a (partially) segregated education system.

However, the problem remains for those States that have strongly segregated education systems. In these States special schools cannot be suddenly closed,

\footnotetext{
${ }^{28}$ CRPD Committee Concluding observations on the initial report of Spain (CRPD/C/ESP/CO/1), 19.10.2011, para. 9 .

${ }^{29}$ See UNICEF (2012).

${ }^{30}$ See Shaw (2014).

${ }^{31}$ See Arnardóttir (2011), pp. 214-215.
} 
because to do so would lead to discrimination against children with disabilities, if these children could no longer receive education. They must instead start immediately with building an inclusive education system, while at the same time the special schools must continue to function. There should be a gradual move from segregated to inclusive education systems, starting from transferring resources from the special schools to the mainstream schools.

Many States, in fact, allocate substantial resources to special education instead to provide mainstream school with the financial means necessary to accommodate special needs. The CRPD Committee has requested that States use these resources for the purpose of inclusive education. ${ }^{32}$

In such countries, the transition towards an inclusive education system can encounter resistance resulting from the legacy of policies and prejudices surrounding children with disabilities, who are considered not to fit in the general education system. There is sometimes a fear that children with disabilities would push the level of education downward and schools are usually not willing to adapt their curricula in order to make them accessible to children with intellectual disabilities in particular. Difficult to remove in historically segregated structures, social barriers are the real obstacles to inclusive education.

\subsection{The Duty to Provide a Reasonable Accommodation}

Article 24 of the CRPD provides for instruments to concretely realize inclusive education systems. One of them, and the most important, is the provision of reasonable accommodation.

According to Article 24 (2) (c) of the CRPD, States shall ensure that 'reasonable accommodation of the individual's requirements is provided'. While this obligation is already foreseen in Article 5 (3), it is repeated in relation to education, which shows its importance for inclusive education. Article 2 of the CRPD defines the concept of 'reasonable accommodation' as follows: 'necessary and appropriate modifications and adjustments not imposing a disproportionate or undue burden, where needed in a particular case, to ensure to persons with disabilities the enjoyment or exercise on an equal basis with others of all human rights and fundamental freedoms'. It furthermore provides that 'denial of reasonable accommodation' is a form of discrimination. Consequently, the provision of reasonable accommodation is an obligation which has to be fulfilled immediately.

Reasonable accommodations are individualized measures meeting the special needs of children with disabilities. They aim at moving beyond formal equality and

\footnotetext{
${ }^{32}$ The Committee recommended to China to 'reallocate resources from the special education system to promote the inclusive education in mainstream schools, so as to ensure that more children with disabilities can attend mainstream education'. CRPD Committee Concluding observations on the initial report of China (CRPD/C/CHN/CO/1), 15.10.2012, para. 36.
} 
achieving substantive equality by ensuring that persons with disabilities can reach the same level of opportunities as other persons. In the field of education, the duty to provide reasonable accommodation means, for example, that buildings and classrooms must be accessible, transportation to schools is available and communication technology is used, as also provided for in Article 9 (1) of the CRPD. Such duty also applies to higher education, as well as to pre-school and adult education, since Article 24 (1) of the CRPD, guarantees 'an inclusive education system at all levels and lifelong learning'. Reasonable accommodations should be provided by public, but also private schools which are prohibited to discriminate since they provide a public service.

The way in which a reasonable accommodation is determined must be decided in consultation with all involved parties, including the applicant(s).

Since education has to be free, reasonable accommodation should likewise be provided by the State, which is responsible for the achievement of inclusive education. In this regard, Article 24 of the CRPD must be read in combination with Article 13 (2) of the International Covenant on Economic, Social and Cultural Rights (ICESCR) providing for free education. ${ }^{33}$ In its Concluding observations to the initial report of Spain the CRPD Committee asked the State to 'ensure that the parents of children with disabilities are not obliged to pay [...] for the measures of reasonable accommodation in mainstream schools, ${ }^{34}$

The question is of course when accommodation is considered 'reasonable'.

This question will never have a definite answer and has to be examined on a case-by-case basis.

It can be considered that accommodations are reasonable if they do not create an undue burden. ${ }^{35}$ There may be a burden, which means that efforts are required, but this burden may not be undue. This involves a comparison between costs, which should be calculated taking into account compensations that can be obtained, and benefits, which includes advantages for parties other than those for whom the measures are taken.

The OHCHR defines 'reasonableness' as 'the result of an objective test that involves an analysis of the availability of resources, as well as the relevance of the accommodation, and the expected goal of countering discrimination'. The OHCHR, however, acknowledges that 'testing standards are yet to be developed in jurisprudence by the Committee on the Rights of Persons with Disabilities'. ${ }^{36}$

\footnotetext{
${ }^{33}$ Article 13 (2) of the ICESCR provides that 'a. primary education must be compulsory and free for everybody; b. secondary education ... in particular through the gradual introduction of free education, must be made generally available and accessible for everybody; [and] c. higher education ... in particular through the gradual introduction of free education, must be made equally accessible based on each person's competence'.

${ }^{34}$ CRPD Committee Concluding observations on the initial report of Spain (CRPD/C/ESP/CO/1), 19.10.2011, para. 44.

${ }^{35}$ See de Campos Velho Martel (2011).

${ }^{36}$ See OHCHR (2013), para. 43.
} 
Significant factors to decide whether hardships are excessive or 'undue' in a school, college or university setting, are indicated in a conference document prepared for the Ad Hoc Committee, such as the financial resources required to provide an accommodation; the degree and kinds of effects that accommodations will have on other students; the impact of accommodations on the educational program itself; unusual risks, if any, that accommodations may pose for staff or other students, including other students who have a disability. ${ }^{37}$

Even though the reasonable character of an accommodation for the purpose of inclusive education is difficult to determine, several sources point out that their cost is often over-estimated and that most of the time they are available. The Handbook for Parliamentarians underlies that experience has shown that as many as 80-90\% of children with specific education needs, including children with intellectual disabilities, can easily be integrated into regular schools and classrooms, as long as there is basic support for their inclusion. ${ }^{38}$

\subsection{Support Measures}

In addition, the CRPD prescribes a number of support measures in order to enable children with disabilities to access the general education system.

According to Article 24 (2) (d) of the CRPD, States Parties guarantee that 'persons with disabilities receive the support required, within the general education system, to facilitate their effective education'. It is worth recalling that the draft proposal mentioned 'effective alternative support measures' to be provided by States Parties in exceptional circumstances of failure of general school, but such expression was to be understood as special education or a mixed form of education. ${ }^{39}$ The obligation to 'ensure that effective alternative support measures are provided' was subsequently replaced by the obligation to 'ensure that effective individualized support measures are provided in environments that maximize academic and social development', which eventually became Article 24 (2) (e). While there remains ambiguity concerning the interpretation of the term 'environments that maximize academic and social development' as special schools, Article 24 (2) (e), provides that the support measures have to be provided 'consistent with the goal of full inclusion'. It could therefore refer more to a mixed form of education than special education.

The support measures supplement reasonable accommodations and differ from them. The support measures are subject to the obligation to progressively realize the

\footnotetext{
${ }^{37}$ The Concept of Reasonable Accommodation in Selected National Disability Legislation. Background conference document by the Department of Economic and Social Affairs, http:// www.un.org/esa/socdev/enable/rights/ahc7bkgrndra.htm.

${ }^{38}$ See UNDESA et al. (2007), p. 85.

${ }^{39}$ See Arnardóttir (2011), p. 217.
} 
right to inclusive education within the maximum available resources (contrary to the duty to provide reasonable accommodation). Support measures are general measures which must gradually achieve inclusive education. Consequently, these measures do not have to be adopted all at once, provided that the available resources are used to achieve inclusive education and that immediate action is undertaken by States in this regard.

Differently from reasonable accommodations which target individuals, support measures aims at adapting the general education system with a view to making it accessible to persons with disabilities. They do not aim at providing for particular adjustments, but to adapt the general education system in order to include all children. It has been noted that while the two overlap to certain extent, the more support measures are taken, fewer reasonable accommodations would be needed since through support measures the general education system would take account of special needs from the outset. ${ }^{40}$

The general measures include providing personal assistance, including medical assistance, as well as the necessary equipment and material, including Braille and sign language, as established in Article 24 (3) of the CRPD. According to the Special Rapporteur on the Right to Education, both external and personal factors should be addressed in order to create inclusive education systems. The former include 'altering the physical environment, such as the design of hallways and classrooms, desks, widening entrances, building ramps, installation of elevators, altering or reconsidering geographical locations, adapting rules and admission standards', whereas the latter entail 'the provision of supplementary classes, alternative/additional forms of communication, special tutors or support staff, and nutritious meals'. ${ }^{41}$ Furthermore, inclusive education requires States Parties to adapt not only teaching methods and curricula but also evaluation tools for children with intellectual disabilities.

As a good example of support measures consistent with Article 24 (2) (d) of the Convention, the OHCHR report indicates the Individual Educational Programme (IEP). ${ }^{42}$ Such programme plays a major role for inclusive special needs education. This document present information on how mainstream curriculum is adapted, and what are the necessary additional resources, goals and evaluation of the educational approach. There is a growing consensus that the provision and implementation of an appropriate IEP is the most effective form of inclusion of pupils with autism. In fact, such programmes affect a child's participation in education, the community, and family life by providing educational objectives aimed at developing social skills, expressive verbal and non-verbal language, cognitive skills, independent organizational skills and so on. ${ }^{43}$

\footnotetext{
${ }^{40}$ See de Beco (2014), pp. 283-284.

${ }^{41}$ See OHCHR (2007), para. 14.

${ }^{42}$ See OHCHR (2013), paras. 46-47.

${ }^{43}$ See Lord and McGee (2001).
} 
A crucial aspect for realizing inclusive education systems is the support given to teaching staff and the quality of its training. Article 24 (4) of the CRPD requires that teachers are trained in how to deal with persons with disabilities and to use alternative or facilitating forms of communication and other methods to support persons with disabilities. Training in disability rights should not only be included in specialization courses but also in general courses which must pay attention to diversity. There are often special teaching curricula for those interested in working with children with disabilities (in special schools), but rarely are those courses integrated into the mainstream teaching curricula. It is also important that teachers continue to be supported and trained during their teaching career.

\section{National Approaches to Inclusive Education of EU Member States}

Different patterns emerge among EU Member States in how they approach their policies for children with SEN. The report of the NESSE network of experts commissioned by the EU Commission in 2012 identifies three distinctive approaches adopted by EU countries. ${ }^{44}$

The first category (called one-track approach) includes States (such as Italy, Greece, Sweden) that develop policy and practices geared towards inclusion of almost all pupils within mainstream education. Generally speaking, this type of integration is supported by a wide range of services focusing on the mainstream school. The percentage of pupils attending special schools or classes is less than $1 \%$.

States belonging to the second category (multi-track approach) have a multiplicity of approaches to inclusion. They do not offer one single solution (inclusion in mainstream education with the support of many different services) or a choice between two options (mainstream or special education). They range from special multiple classes (full-time or part-time) to different forms of inter-school cooperation including exchange categories (with teacher and pupils from mainstream and special schools arranging temporary or part-time exchange). States like Denmark, France, United Kingdom fall into this category.

In the third category (two-track approach), there are two distinct education systems. Pupils with SEN are usually placed in special schools or special classes. Generally, a vast majority of pupils officially as having special educational needs do not follow the mainstream curriculum among their non-disabled peers. In this way, mainstream and special schools run in parallel. Switzerland and the Flemish Community of Belgium belongs to this category.

However, the NESSE report highlights that at times it can be difficult to classify a country according to the type if inclusion policy, because of policy changes.

\footnotetext{
${ }^{44}$ See NESSE (2012).
} 
For instance, Germany and the Netherlands are positioned within the two-track system but they are recently moving towards the multi-track system. There is, in fact, a common trend in Europe consisting in transforming special schools and institutes into resource centres. These centres are given different names and different tasks are assigned to them, such as provision for training and course for teachers and other professionals, development and dissemination of materials and methods, support for mainstreams schools and parents, short-time or part-time help for individual students. Special education resources can support mainstream schools in the integration process.

\section{EU Member States' Implementation of Article 24}

In its Concluding observations, the CRPD Committee has stressed the importance of enabling children with disabilities to obtain education, and preferably inclusive education where children with disabilities are alongside other children in the classroom. $^{45}$

Implementing inclusive education is high on the agenda of many EU Member States, though the policy is approached from differing historical and structural perspectives.

For instance, there are EU Member States with selective rather than comprehensive school systems where special schools are still numerous. Germany and both the French and Flemish communities of Belgium may be cited as examples in this regard.

In Germany, special schooling has a tradition in the field of child education. The country has a highly differentiated (segregated) system that is based on a division between regular schooling and special schooling. When the CRPD came into force in 2009, $85 \%$ of persons with recognized special needs attended special schools. $^{46}$

The right to education is stated in the Basic Law (Grundgesetz, Art. 3-R1) and in Book Twelve of the Social Code (Sozialgesetzbuch XII-Sozialhilfe). However, in such country education is a matter for the Länder and therefore the right of disabled pupils to education and training appropriate to their needs is stated in the Länder constitutions and more detailed provisions are set out in their educational legislations. So far, only some States have adopted a co-education system of disabled and non-disabled children in school.

In its Report on the CRPD implementation, the German Federal Government referred about its endeavours in ensuring that inclusive learning becomes the norm in Germany, by harmonizing the development and the organization of special education in the Länder through the resolutions adopted by the Standing Conference of the Ministers of Education and Cultural Affairs of the Länder. In this vein,

\footnotetext{
${ }^{45}$ See OHCHR (2013), paras. 26 ff., 56 ff., 68 ff.

${ }^{46}$ See German Institute for Human Rights (2014), p. 17.
} 
the Recommendations of the Conference of Ministers of Culture and Education are being revised in order to address some specific issues such as the teaching of children with autism. The current situation is documented in the Recommendations on Special Needs Education in the Schools of the Federal Republic of Germany (Empfehlungen zur sonderpädagogischen Förderung in den Schulen in der Bundesrepublik Deutschland, Resolution of May 1994), which form the basis for the development at Land level in the field of special education. In 2000, the Standing Conference has also made Recommendations on the Education and Teaching of Children and Young People with Autistic Behaviour (Erziehung und Unterricht von Kindern und Jugendlichen mit autistischem Verhalten).

The CRPD Committee has not yet adopted its Concluding observations on the initial report of Germany and therefore its views on the German education system and the action undertaken for increasing inclusive education are not known.

However, it is worth to mention that the Committee on the Rights of the Child expressed its concerns about the non-inclusive nature of education in Germany, particularly at the secondary school level. In that context, the Committee also noted with concern that in certain Länder, children at the primary level are assigned to special schools against their parents' will, the vast majority of pupils with disabilities attend special schools, and a high number of children with disabilities leave school without a diploma. Furthermore, the need for individual support and reasonable accommodation in the area of education is not recognized. ${ }^{47}$ Consequently, the CRC Committee urged Germany to take 'all necessary legislative and structural reforms to ensure that the right to inclusive education is guaranteed to children with disabilities and provide for it to encompass the right to individual support and reasonable accommodation in the area of education'.

Discrepancies in education organization exist also in Belgium, where each community (Dutch speaking community, French speaking community and German speaking community) has its own education system. Special needs education is spread over the different communities and types of educational institution take the form of special schools or integrated education.

In Flanders, special schools have been established by the 1970 Special Education Law whereby special schools are organized on the basis of the type of disabilities (primary level) ${ }^{48}$ and pedagogical programme of education (secondary level). ${ }^{49}$ The establishment of this categorical approach led to a proliferation of

\footnotetext{
${ }^{47} \mathrm{CRC}$ Committee Concluding observations on the combined third and fourth periodic reports of Germany (CRC/C/DEU/CO/3-4), 31.1.2014, paras. 50-55.

${ }^{48}$ At primary level, special education is organized for type of disabilities, such as Type 1: children with mild intellectual disabilities; Type 2: children with moderate or severe intellectual disabilities; Type 3: children with serious emotional and/or behavioural problems; Type 4: children with physical disabilities; Type 5: children admitted to hospital or in quarantine for medical reasons; Type 6: children with visual impairments; Type 7: children with hearing impairments; Type 8: children with serious learning difficulties.

${ }^{49}$ At secondary level, special needs education is subdivided in training forms (TF), namely TF1: offering social training with the aim of integration into a protected environment (for students of
} 
new-built special schools and the closure of existing special classrooms in regular schools, creating a problematic structural legacy in subsequent moves towards an 'inclusion agenda'. In order to address such problem, in 1986 the Law was amended to give students with disabilities the opportunity to receive a supported education in a mainstream school. Accordingly, children with disabilities may be to a certain degree educated within mainstream education according to the system of integrated education or the inclusive education project.

Integrated education can be organized on all educational levels. It aims at children with (a) minor mental disabilities, (b) serious emotional and/or behavioral problems, (c) physical disabilities, (d) visual disabilities, (e) auditory disabilities or (f) serious learning disabilities. Such kind of education comprises attendance in mainstream education classes mixed with additional teaching periods and/or additional resources provided by a school for special education.

Children with a moderate or severe mental disability are not covered, but may be qualified for participating in the mainstream school through the Inclusive Education Project (Inclusief Onderwijs) or ION, by which students receive individual learning-pathway support.

However, the Law limited the program to 100 students and no special type of class for children with ASD was provided, so children with ASD who choose to attend a special education school, as a result, were scattered over different types of special schools where ASD adaptations and teaching expertise are inappropriate.

In order to increase inclusive education, a Decree adopted in 2002 on equal education opportunities (GOK Decree) established that mainstream primary and secondary education may enroll a pupil with SEN, but it is allowed to refuse the enrolment if the school does not have sufficient means to provide for the pupil's specific needs in terms of teaching. In this case, the pupil is referred to special needs education.

The education system in Belgium is not consistent with Article 24 of the CRPD that establishes the right to mainstream education for all people with disabilities. In fact, the CRPD Committee in its Concluding observations on the Belgium initial report expressed its concern on the segregate education system in Belgium, underlying the high number of students of disabilities obliged to be enrolled in special schools in reason of the missing of reasonable accommodations in the ordinary education system. ${ }^{50}$

In March 2014, the Flemish Parliament passed the Decree concerning measure for pupils with specific educational needs, known as the 'M-decree', aimed at

types T2, T3, T4, T6, T7); TF2: offering general and social training with the aim of integration into a protected environment and work situation (T2, T3, T4, T6, T7); TF3: offering social and vocational training with the aim of integration into a regular environment and work situation (T1, T3, T4, T6, T7); TF4: offering preparation for study in higher education and integration into active life (T3, T4, T5, T6, T7).

${ }^{50} \mathrm{CRPD}$ Committee Concluding observations on the initial report of Belgium (CRPD/C/BEL/CO/ 1), 28.10.2014, paras. 36-37. 
ensuring greater access to mainstream education for children with disabilities. ${ }^{51}$ Such Decree introduces a new Type 9 for 'children with autism without intellectual disabilities' within the system of disability typologies under which is assessed if a students have special needs.

Providing the right for reasonable accommodation, the M-decree establishes that students can be referred to special education only if schools can prove that they have tried all 'reasonable adjustments'. In particular, it states that every child with disability has the right to be enrolled in regular school if it is possible to follow the regular curriculum with reasonable adaptations, such as extra-time to make tests.

As for the children with disabilities who need an individual curriculum, the M-decree points out that they can go to regular school if the student support service and the teaching staff concludes that it is possible with reasonable adaptations. When adaptations are too extreme, the child will be referred to special education.

Being the entry into force of the Decree, originally scheduled in September 2014, delayed until September 2015, the effect of the new law once it is in force is unknown.

However, the M-decree has raised several criticisms from DPOs. As underlined in the complaint submitted by the MDAC to the European Committee of Social Rights in $2014,{ }^{52}$ the Decree appears to be discriminatory since it does not even apply to children who cannot follow the regular curriculum, thereby excluding children with more significant intellectual or learning disabilities. Furthermore, no new funding mechanisms have been introduced in order to increase the number or range of supports that schools or local authorities can provide to students who require accommodations. Therefore, it seems that the $\mathrm{M}$-decree will not change the current practices by which schools refuse admission to students claiming that they cannot provide the needed supports if considered disproportionate and an undue burden.

In contrast with clearly separated systems, some EU Member States, such as the UK and Spain, have some provisions on special education while a comprehensive school system has been established.

As far as the United Kingdom is concerned, mainstream school system co-exists with special schools. In this regards, it must be recalled that the State made a reservation on Article 24 of the CRPD stating that 'the general education system in the United Kingdom includes mainstream, and special schools, which the UK Government understands is allowed under the Convention'. Such reservation is aimed at enabling parents to continue to have access to places for their children at mainstream and special schools. ${ }^{53}$

\footnotetext{
${ }^{51}$ The entry into force of the decree which was originally scheduled for September 2014, was delayed until September 2015.

${ }^{52}$ European Committee of Social Rights Mental Disability Advocacy Center (MDAC) v. Belgium, Complaint No. 109/2014. https://www.coe.int/t/dghl/monitoring/socialcharter/Complaints/ CC109CaseDoc1_en.pdf. Accessed 17 Sep 2014.

${ }^{53}$ The UK reservation reads as follow: 'The United Kingdom reserves the right for disabled children to be educated outside their local community where more appropriate education provision
} 
Discrimination against people in education is prohibited in Great Britain by the 2010 Equality Act and in Northern Ireland by the 2005 Special Educational Needs and Disability Order. Both acts provides that schools must take reasonable accommodation ('steps' in the 2010 Equality Act, 'adjustment' in the 2005 Order) to ensure equal access to all areas of school life.

In England, the education system for children and young people with SEN or disability, under the terms of the 1996 Education Act, has been reformed following the Children and Families Act entered into force in September 2014.

The Act is committed to inclusive education of disabled children and young people and to progressively remove the barriers to their learning and participation in mainstream education. The Children and Families Act secures the general presumption in law of mainstream education in relation to decisions about where children and young people with SEN should be educated.

It places duties on local authorities and other services in relation to both disabled children and young people and those with SEN, although not all the sections of the Act apply to both groups. The strategic planning duties generally apply to all disabled children and young people and those with SEN. The specific duties, in particular those contained in Part 3 of the Act, apply only to children and young people with SEN, while duties to disabled people are contained in the 2010 Equality Act.

The Act incorporates the definition of SEN contained in the 1996 Education Act. A child or young person has special educational needs if they have a learning difficulty or disability which calls for special educational provision to be made for them (Section 20). Special educational provision is additional to or different from that which would normally be provided for children or young people of the same age in a mainstream education setting (Section 21).

Statements of special educational needs for children in schools are replaced with a combined Education, Health and Care plan (EHC plan), which includes health and social care support that is required as well as education provisions. In the field of education the plan specifies, inter alia, the child's or young person's special educational needs, the outcomes sought for him or her and the special educational provision required by him or her. Many of the legal requirements for EHC plans are the same or similar to those required for SEN statements, but significant differences exist as far as their duration. EHC plans covers the age range 0-25 years. Therefore, such plans do not necessarily cease when a young person leaves school and can be maintained when a young person is in college, undertaking an apprenticeship, or not in education, employment or training.

Section 33 of the Act places a duty on the local authority to ensure that a child or young person with an EHC plan is educated in a mainstream setting. The only

is available elsewhere. Nevertheless, parents of disabled children have the same opportunity as other parents to state a preference for the school at which they wish their child to be educated. The United Kingdom Government is committed to continuing to develop an inclusive system where parents of disabled children have increasing access to mainstream schools and staff, which have the capacity to meet the needs of disabled children'. 
exceptions to this rule are if this goes against the wishes of the young person or the child's parent, or would impact on the efficient education of others and there are no reasonable steps that could be taken to overcome this incompatibility.

Within the UK, the educational provisions for students with SEN broadly operates under similar legislative framework. Nonetheless, it is worth to mention some main innovations introduced outside England.

In Scotland, the legal framework substantially changed with the 2004 Education Additional Support for Learning Scotland Act, by which the term SEN has been replaced by the broader definition of 'additional support need', referring to all children who would benefit from extra-help for overcoming barriers to their learning.

In Wales, where the legal framework for the provision of special education is governed by the 2002 Education (SEN) Welsh Regulation, in June 2014 the Government has published a White Paper which proposed to change the law. The reform, which will apply to learners aged 0-25, will replace the existing statutory definition of SEN with a more flexible and inclusive legal concept of Additional Learning Needs (ALN) and substitute statements of SEN with Individual Development Plans (IDPs) as the basis for meeting a child or young person's ALN.

The organization of special educational provision and the definition of SEN in Northern Ireland are similar to those employed in England. Special education is governed by the 1996 Education (Northern Ireland) Order as amended by the 2005 Special Educational Needs and Disability (Northern Ireland) Order, by which special educational needs are addressed in special schools, special units attached to mainstream schools, or in mainstream classes.

In Spain, the concept of special education has been introduced by the 1990 Organic Law of General Arrangement of the Educational System (LOGSE), which asserted the incorporation of special education into mainstream system and stated that SEN pupils can attend mainstream or special education establishments. This Act established that pupils with special educational needs should attend mainstream setting, by adapting regular programmes to the individual capacities of each pupil. Their schooling in special education units or establishments, or a combined schooling, only took place when pupils' needs cannot be met in mainstream establishments.

Following LOGSE, Spain progressed in its efforts to promote inclusive education adopting new provisions for students with special needs.

The current 2006 Organic Law of Education (LOE) is based on the principle that the same quality of education has to be provided for all pupils, regardless of their condition or circumstances, on the assumption that guaranteeing equality of opportunities, educational inclusion and non-discrimination serves as an element for compensating personal, cultural, economic and social inequalities, with special emphasis on inequalities arising from disability.

Part II of the Law deals with students with special educational needs who require certain support and specific educational attention due to disability or serious behavioral disorders, either for a period or throughout the whole of their schooling. 
The schooling of students with SEN will be governed by principles of normalization and inclusion and will ensure non-discrimination and real equality in the access to the education system and continued attendance, allowing flexibility in the different stages of their education when necessary. Schooling in special education centres or units, which may be extended to the age of 21 , will only take place when their needs cannot be met by the special needs provisions available in normal schools.

In pursuance of the LOE, royal decrees have been issued laying down minimum educational content in the three stages of schooling-pre-primary, primary and secondary. Such decrees envisage the provision of necessary support for students with SEN from the beginning of their schooling or as soon as they are identified as having special needs. In principle, schools have to guarantee appropriate scholastic organization in order to enable every pupil to attain the educational goals, as well as they have to ensure available the personnel and material resources needed to provide appropriate care for pupils with educational needs deriving from disabilities. The schools develop the curriculum through Individual Educational Plans (IEP), which have to take into account the student's needs and characteristics.

Following such legal instruments, significant results have been achieved in Spain. Most children with disabilities follow regular education system and the overall number of special schools in Spain has tended to decrease. While some special institutions have been transformed into resources centres, others have been dismantled as a result of inclusive policies, but still exist. ${ }^{54}$

In spite of such evolution, the CRPD Committee raised concerns on the implementation of Spanish laws in practice. In particular, in its Concluding observations on Spain's report the Committee stressed on the reported cases of failure to provide reasonable accommodations or of enrollment in special schools, even against parents' will. In this regard, the Committee noted with concern that parents challenging the placement of their children with disabilities in special education have no possibility of appeal and their only alternative is to educate them at their own expense or pay for the reasonable accommodation of their child in the regular education system. ${ }^{55}$

Finally, there are EU countries that in the absence of any historical tradition of special schooling, educate almost all children in mainstream schools.

Italy is boosting an advanced regulatory framework regarding the inclusion of pupils with disabilities in mainstream classes. In Italy the movement supporting inclusion in mainstream education dates back to the end of the 1960s and has led to a widespread and broadly discussed experience.

\footnotetext{
${ }^{54}$ See Rotatori et al. (2014).

${ }^{55}$ CRPD Committee Concluding observations on the initial report of Spain (CRPD/C/ESP/CO/1), 19.10.2011, para. 43 .
} 
Inclusion for pupils with disabilities began with Law 118/1971, which granted all children the right to be educated in common classes, and with Law 517/1977, ${ }^{56}$ which abolished special schools. In 1992, the whole process led to Law 104, a general legislative framework, which tries to meet the complex needs of disabled people more systematically over the different stages of their life.

With regards to education, Article 12 of Law 104/1992 states that all persons with disabilities, 'regardless of their type and degree of disability', attend mainstream education from kindergarten to the level of education that they are able to attain according to their personal capacities (Article 12). In this perspective, the Law provides for the removal of barriers (architectural or sensorial) and the introduction of appropriate aids and tools to support pupils with disabilities in education and training. In particular, this Framework Law ensures coordinated planning of educational, health, social, cultural, leisure and sport services for students with disabilities and it requires that schools are provided with technical equipment and educational materials as well as any other kind of technical help (Article 13).

In compliance with Law 104/92, school inclusion of children with disability is organized on the basis of Individualized Educational Plans (PEI), taking into account the necessary adjustments for students with disabilities. Following the identification of student's capabilities and potentialities, a PEI is drawn up by including the general lines of the didactic project of scholastic and social inclusion. The individualized educational plan is jointly worked out by specialized teachers, health and education professionals and parents. ${ }^{57}$

\footnotetext{
${ }^{56}$ Law 517/1977 provided a series of service delivery parameters to support inclusive education such as: (a) specially trained support teachers (insegnante di sostegno) were to be paired with classroom teachers with the intention that they would work together to improve educational opportunities for all students, thus mitigating stigma for students with disabilities; (b) no more than 20 students were to be in classes that included a student with a disability, and (c) extracurricular activities must provide access for all students.

${ }^{57}$ Such plan results from the other tools provided by Law 104/1992 for challenging the functions and the potentials of the disabled child as much as possible: the functional diagnosis and the dynamic-functional profile.

The functional diagnosis aims at identifying a child as an individual with a disability and to gather information about the child's history and hisher family. It is filled in by a team of specialists in different fields of disability. It specifies the kind and the level of disability and the functioning profile of the child on the basis of: affective-emotional (identity and relations with other persons), cognitive, motor-sensorial, communicative and linguistic features, neuropsychological competences (attention memory and space-time organization), self-help and autonomy capabilities. It is filled in according to the ICF model (International Classification of Functioning 2001).

The dynamic-functional profile is an educational tool to sketch a global profile of the disabled child, aiming to answer the question: what are the best objectives for "this" child, on the basis of his her diagnosis, his ไher actual performance, the life skills and the life project that child, family, and professionals foresee for himselfherself? The dynamic-functional profile is the link between the developmental level of the child and the methodology of the individualized educational programme.
} 
Further legal instruments focused on the special needs of students with learning disabilities, namely Law 170/2010 New rules on Specific Learning Disabilities in School $^{58}$ — and Ministerial Directive of 27 December 2012 Intervention tools for children with special educational needs and territorial organization for inclusion in schools.

By endorsing the concept of special educational needs, the 2012 Ministerial Directive converged the Italian school system on the point of view that not only disabled students, but also students with special needs, namely due to specific language or learning impairments or to social-cultural disadvantages, need particular attention from the school. Such Directive responds, in fact, to the practice of not labeling high disabilities as such as learning disabilities, with the result that only $2 \%$ of students are certified (or identified) as having special needs in Italy. ${ }^{59}$

The Directive deals with the initiatives to be taken for different types of pupils with SEN: pupils with assessed disabilities, with specific developmental disorders or with socio-economic, linguistic and cultural disadvantages. It provides for the personalization of learning paths for all SEN students through the adoption of an Individualized Didactic Program, identifying learning abilities and methodological strategies. It also extends tools and measures provided by Law 170/2010 for the SLD students to further include all students with special educational needs. Therefore, SEN students are entitled to receive compensative measures, namely facilitative and technological tools, and dispensatory measures, i.e. exoneration from some performances, extra-time, reduction of school works.

In order to strengthen the inclusion policy, the Ministerial Directive stresses on the need to make all the scholastic community, not only some teachers, responsible for the inclusion for all kind of special needs. In this vein, it foresees the training of all teachers in the field of disability, also by the institution of a Master's degree dedicated to didactics and psycho-pedagogy for the various forms of disturbance or disability and the enhancement of territorial centres (CTS) with specialized teachers that can support schools in the inclusive policy and promote good practices.

Notwithstanding Italy is continuing to refine its model of inclusion, many challenges to inclusive education remains mainly reflecting gaps in implementation of the law. Such challenges varies from the lack of accessible schools and transportation systems to the shortage of trained teachers and precariousness of support

\footnotetext{
${ }^{58}$ Law 170/2010 recognises dyslexia, dysgraphia, dysorthographia and dyscalculia as specific learning disorders (SLD). This Law states that pupils with learning disorders do not need special teachers, but rather a new way of teaching, according to their way of learning. Amongst the measures provided by the Law, students can use speech synthesis tools, which allow them to learn by listening rather than reading, tape recorders which let them listen to lessons, word-processing programmes with spelling checkers and many more. University students with SLD have the right to these compensatory and dispensatory measures from the moment of the admission test.

${ }^{59}$ See Giangreco et al. (2012).
} 
teachers for students with disabilities, to cases of micro exclusion perpetuated in ordinary settings. ${ }^{60}$

In order to improve the quality of inclusive education in Italy, a Bill have been presented to the Italian Parliament in 2014. Such Bill provides for the continuity of support teachers by establishing specific figures for the didactic support in each educational level and proposes the replacement of the functional diagnosis and the dynamic-functional profile with the functioning profile to be elaborated not only by medical specialists but also by families and teachers. Furthermore, in order to fully comply with Article 24 of the CRPD, the Bill introduces the specific duty to provide reasonable accommodations.

\section{Conclusions}

The inclusion concept entails that everyone is equal and should stand in the same position at the starting point with the others even if the achievement of such goal requires the provision of individualized measures. Giving a legally binding status to the right to inclusive education, the CRPD has stimulated an important discussion throughout the world about inclusion in education of children with disabilities.

There is no best practice model of inclusive education. Inclusion is, indeed, a difficult path, and it is undoubtedly impossible to state that 'all has been done' since inclusion is a process that must continually be reviewed and revised. So, there is a great deal of progress to be made in fulfilling the obligation of inclusive education for children with disabilities.

Improving inclusive education means to fully comply with Article 24 of the CRPD looking at the authoritative interpretation of such provision made by the CRPD Committee. In fact, a number of key themes emerged from the UN Committee's Concluding observations, such as the need to develop a comprehensive State education policy that guarantees the right to inclusive education; the prohibition of forced enrolment in special education settings and the provision of effective and swift appeal against decisions on student's placement; the immediate applicability of the duty to provide reasonable accommodation, the allocation of sufficient financial and human resources to implement the right to inclusive education; the quality training of teachers and all other educational staff to enable them to work in inclusive educational settings.

The current tendency in EU Member States is to develop a policy towards inclusion of pupils with special educational needs. In some countries, there is still a selective rather than an inclusive education system, but some advancements have been put in place. For instance, in European countries with a relatively two-track

\footnotetext{
${ }^{60}$ See D'Alessio (2011). The author reports that some schools in Italy are establishing new separate support room (known as aule del sostegno), where support teachers take students out of regular supports or services in segregated settings.
} 
system of special needs education there is a trend to developing a continuum of services between the two systems or transforming special schools as resources centres for mainstream schools. ${ }^{61}$

On the contrary, some EU Member States, such as Italy or UK, have long been leaders in protecting the right to inclusive education of children with disabilities and their legal systems have much to offer as implementing practice of Article 24 of the CRPD.

However, many challenges to realizing the goal of full inclusion remain reflecting, in many cases, gaps in implementation of the law, due also to economic constraints. Even in more advanced inclusive system, most laws have yet to be fully implemented. While it is considered perhaps the most inclusive education system in the world, ${ }^{62}$ Italy serves as an important reminder about the many challenges of translating the language and values of law into practice.

Article 24 of the CRPD calls for an inclusive education system which should be flexible to meet the special needs of people with disabilities. Adjustments are especially needed to address ASD pupils' needs, for whom education cannot rely on centrally-determined curricula and teaching methodologies and, therefore, an individually tailored educational plan based on a set of individualized objectives should be provided. Qualified by the OHCHR has a good example of support measures consistent with Article 24 (2) (d) of the CRPD, the Individual Educational Plans (IEPs) take into account the needs of the individual child and his/her family, and require to adapt the child's schedule and educational environment, both in and out of the classroom. In order to meet the needs of pupils with ASD, such plans should be intended as a global plan including didactic, rehabilitative, social and welfare aspects, like the PEI in Italy and the EHC plans in England.

There will be some pupils with ASD whose autism is so severe that they will need a specialist support, but it does not need to be in a segregated setting. The best model is where the child with autism belongs to his peer group teacher but has the support of staff with expertise and a 'haven' in which to recover when needed. ${ }^{63}$

There is still a role for specialist schools, but to be consistent with Article 24 of the CRPD they must have a better reason for their existence than that they pick up those who 'fail' in mainstream schooling. As it is occurring in Europe, specialist schools should be centres of excellence, pioneering new ways of working with ASD and dealing with the most extreme cases. They should be centres of research as well as teaching and have a role in working alongside mainstream schools to bring about more effective inclusion. However, special schools must be seen more as supports for an inclusive system rather than an alternative to it.

\footnotetext{
${ }^{61}$ See Meijer (2010).

${ }^{62}$ See Kanter et al. (2014), p. 29.

${ }^{63}$ See Jordan (2008), p. 13.
} 
Open Access This chapter is distributed under the terms of the Creative Commons Attribution Noncommercial License, which permits any noncommercial use, distribution, and reproduction in any medium, provided the original author(s) and source are credited.

\section{References}

Arnardóttir O (2011) The right to inclusive education for children with disabilities - innovations in the CRPD. In: Eide A, Möller J, Ziemele I (eds) Making peoples heard. Essays on human rights in honour of Gudmundur Alfredsson. Martinus Nijhoff Publishers, Leiden/Boston, pp 219-221

D'Alessio S (2011) Inclusive education in Italy. A critical analysis of the policy of Integrazione Scolastica. Sense Publishers, Rotterdam

de Beco G (2014) The right to inclusive education according to Article 24 of the UN Convention on the rights of persons with disabilities: background, requirements and (remaining) questions. Netherland Q Hum Rights 3:263-287

de Campos Velho Martel L (2011) Reasonable accommodation: the new concept from an inclusive constitutional perspective. Int J Hum Rights 8(14):85-103

German Institute for Human Rights (2014) Submission of the National CRPD monitoring body of Germany to the CRPD Committee on the rights of persons with disabilities on the occasion of the preparation of a list of issues by the Committee in the review of Germany's initial report in 2014. http://www.institut-fuer-menschenrechte.de/uploads/tx_com merce/Submission_of_the_National_CRPD_Monitoring_Body_of_Germany_to_the_CRPD_ Committee_on_the_occasion_of_the_preparation_of_a_list_of_issues_by_the_Committee_ in_the_review_of_Germanys_Initial_Report_2014.pdf. Accessed 17 Sep 2014

Giangreco MF, Doyle MB, Suter JC (2012) Demographic and personnel service delivery data: implication for including students with disabilities in Italian schools. Life Span Disabil 15 (1):97-123

Jordan R (2008) Autistic spectrum disorders: a challenge and model for inclusion in education. $\mathrm{Br}$ J Spec Educ 35(1):11-15

Kanter AS, Damiani ML, Ferri BA (2014) The right to inclusive education under international law: following Italy's lead. J Int Spec Needs Educ 17(1):21-32

King M (2006) How law defines the special educational needs of autistic children. Child Fam Law Q 18(1):23-42

Lord C, McGee JP (eds) (2001) Educating children with autism. National Research Council, Committee on Educational Interventions for children with autism. National Academy Press, Washington, DC

Meijer JW (2010) special needs education in Europe: inclusive policies and practices. Zeitschrift für Inklusion-online.net. http://www.inklusion-online.net/index.php/inklusion-online/article/ view/136/136. Accessed 17 Sep 2014

NESSE-Network of Experts in Social Sciences of Education and Training (2012) Education and disability/special needs. Policies and practices in education, training and employment for students with disabilities and special educational needs in the EU. http://www.nesse.fr/nesse/ activities/reports/activities/reports/disability-special-needs-1. Accessed 17 Sep 2014

Reindal SM (2008) A social relational model of disability: a theoretical framework for special education? Eur J Spec Needs Educ 23(2):135-146

Renty J, Roeyers H (2005) Students with autism spectrum disorder in special and general education school in Flanders. Br J Dev Disabil 1(100):27-39

Rotatori AF, Bakken JP, Burkhardt S, Obiakor FE, Sharma U (eds) (2014) Special education international perspectives: practices across the globe. Emerald Group Publishing Limited, Bingley 
Shaw B (2014) Inclusion or choice? Securing the right to inclusive education for all. In: Sabatello M, Schulze M (eds) Human rights \& disability advocacy. University of Pennsylvania Press, Philadelphia, pp 58-63

UNDESA-Department of Economic and Social Affairs, OHCHR-Office of the United Nations High Commissioner for Human Rights, IPU-Inter-Parliamentary Union (2007) From exclusion to equality. Realizing the rights of persons with disabilities. Handbook for parliamentarians on the Convention on the rights of persons with disabilities and its optional protocol. United Nations, Geneva. http://www.un.org/disabilities/documents/toolaction/ipuhb.pdf. Accessed 17 Sep 2014

UNESCO (2009) Towards inclusive education for children with disabilities: a guideline. UNESCO Bangkok, Bangkok

UNICEF (2012) The right of children with disabilities to education: a rights-based approach to inclusive education. Position Paper. http://www.unicef.org/ceecis/IEPositionPaper_ ENGLISH.pdf. Accessed 17 Sep 2014

Rachele Cera is Researcher at the Institute for International Legal Studies of the Italian Researcher Council (ISGI-CNR), Rome, Italy. 